\title{
The Impact of Using the Emotional Intelligence on the Effectiveness of the Leadership in Decision-Making in the Jordanian Business Organizations: An Empirical Study on the Working Banks in the Northern Governorate of Irbid, Jordan
}

\author{
Hamdan Rasheed Abdullah Al-Jammal \\ Associate Professor, Department of Financial and Administrative Sciences \\ Faculty of Huson Collage, Balqa Applied University \\ Jordan
}

Email: dr.hamdan_aljammal@yahoo.com

Received: October 26, 2016 Accepted: November 18, 2016 Published: December 02, 2016

doi:10.5296/ijhrs.v6i4.10338 URL: http://dx.doi.org/10.5296/ijhrs.v6i4.10338

\begin{abstract}
The study is concerned with the emotional intelligence in the surveyed organizations and its impact on them as well as on its employees. The researcher collected data and information from primary and secondary sources through preparing a questionnaire and determining its four axes: self-awareness, self-control, emotional balance and adopting the democratic style at work and distributing it to managers and their assistants in the banks mentioned in the study population. The study reached to the following results:

1. The study found that there is a relationship between self-awareness (self-realization) and the effectiveness of leadership in decision-making, where leaders exceed all their problems in the past, be able to determine the feelings of others toward them, show enthusiasm in dealing with employees, enjoy making friends with them, and deal objectively with all the issues in the organization.

2. The study found that there is a relationship between self-control and the effectiveness of leadership in decision-making, where leaders are open to employees in a codified method to keep calm, feel scared of talking in meetings, do not feel a sense of anger at criticizing any of the employees, involve their emotions and feelings when discussing with any employee,
\end{abstract}


show their anger during discussing with any employee, make others feel they are liked during discussion and finally listen well and not interrupting others.

3 - The study found that there is a relationship between the emotional balance and the effectiveness of leadership in decision-making, where leaders held themselves accountable after each discussion, sit in quiet and contemplative sessions after work, are able to solve problems quietly, and are characterized with flexibility in dealing with their problems.

4. The study found that there is a relationship between adopting the democratic style and the effectiveness of leadership in decision-making, where leaders do not allow others to participate in the traditional decisions, consult some employees when making decisions, involve employees in taking vital decisions, collect data and information before making decisions, delegate some employees with decision making, hold employees responsible for the wrong decision, and employ emotions when trying to convince others with a certain decision.

The study recommended that there should be programs to develop the leadership ability to strengthen the sense of the self-awareness of managers and other employees in the field of decision-making. Furthermore, Leaders should exceed all their previous events that may adversely affect the work of the organization not allowing them to affect them negatively when making decisions or dealing with employees.

Keywords: Emotional intelligence, Leadership styles, Empirical analysis

\section{Introduction}

\subsection{Study Importance}

The importance of the study stems from the importance of the surveyed subject where the success key of the organizations totally depends on the emotional intelligence of leaders and managers in decision-making; when taking decisions, the psychological and social factors of the employees are taken into consideration. The subject of emotional intelligence has become one of the topics that raise many questions.

The effectiveness of leadership refers to the ability of the leader to identify and understand the needs of employees being one of the basic emotions and determinants of the human behavior; therefore, it is important to identify them and figure out their role in the success of the leadership behavior rather than limiting them.

The search has a great importance since it handles a new psychological concept practiced by the administration during work in a conscious and unconscious way; therefore, the emotional intelligence is an indicator of the professional and social success of organizations, which identify the leadership behavior and effectiveness.

\subsection{Study Objectives}

This study aims to identify the impact of using the emotional intelligence on the effectiveness 
of leadership in taking decisions since it is natural that the decision-making process takes into account the emotional, psychological and social factors of all employees; one of the dimensions of emotional intelligence is expressing the individual's ability to control his emotions and feelings with other employees whether they are heads of departments or subordinates leading to the success of both the organization and individuals as well as increasing their satisfaction and productivity.

The objectives of the study can be determined with the following goals:

1-identify the extent of using the emotional intelligence by the administration.

2-identify the level of the effectiveness of leadership among the senior and middle management executives.

3- Determine the relationship between the emotional intelligence and the effectiveness of leadership among the employees in the senior and middle management

4- Identify the impact of the emotional intelligence on decision-making

\subsection{Study Problem}

Decision-making is the most important and dangerous business conducted by the senior and middle management in the organization due to the importance and effect of the decision on the organization during taking, receiving and conducting it in the near or far extent. The process of choosing among alternatives and executing them in addition to the costs and the predicted return are significantly affected by the psychological, emotional and social factors of employees.

The problem of the study is represented by the following questions:

1. Do the senior and middle management in the organization apply the methods of the emotional intelligence in decision-making?

2. To what extent are the senior and middle management able to use their emotions and express them during decision-making?

\subsection{Study Hypotheses}

- There is a statistically significant relationship at (0.05) between the level of the emotional intelligence and the leadership effectiveness in the senior and middle management in decision-making.

\subsubsection{Sub-hypotheses}

There is a relationship between self-awareness (self-realization) and the effectiveness of leadership in decision-making.

There is a relationship between self-control and the effectiveness of leadership in decision-making.

There is a relationship between the emotional balance and the effectiveness of leadership in 


\section{MInstitute"}

decision-making.

There is a relationship between following the democratic style and the effectiveness of leadership in decision-making.

\subsection{Study Variables}

1.5.1. The independent Variable

Self-awareness or self-realization

Self-control

Emotional balance

Democratic style

1.5.2. The dependent Variable

Making Decisions

\subsubsection{Demographic Variables}

Sex, experience, educational qualification

\subsection{Operational Definitions}

Emotional Intelligence: our ability to understand our emotions and the emotions of others and learn to deal with oneself and with others and that our control on our emotions is the basis of our will and personality.

\subsubsection{Self-awareness: self-realization (awareness of self-feelings)}

It is represented in the individual's understanding of himself and others so he can be continually connected to his feelings and able to express them and determine the needs associated with them. It is also represented in the ability of those in charge of identifying and understanding the personal feelings and the things that motivate us and the effect of that on others. It includes attributes like self-confidence and objectivity in evaluating your abilities.

\subsubsection{Self-control}

The ability to control and direct strong emotions and feelings toward others

\subsubsection{Motivation}

Love of work, regardless of the physical interests

\subsubsection{Empathy}

The ability to understand the feelings and emotions of others, as well as the skill in dealing with them

\subsubsection{Making decisions}

Choosing the alternative from the available ones in the organization to solve a particular 
problem based on the expected costs and return for each alternative.

\subsubsection{Self-stimulation}

Self-motivation and self-control and persistence where hope is the main component of motivation

(Bar-On \& Parker, 2000) states that it is the positive outlook of the individual towards different things being a source of pleasure to those around him and enjoying the feelings of satisfaction and optimism.

\subsection{Study Population}

The researcher considers all employees in the executive management in the operating banks in the north of Jordan in Irbid Governorate listed in the appendix: the Islamic Bank, the Arab Bank, Al Rajhi Bank, the Bank of Jordan, and Cairo Amman Bank amounting to (250) employees in the executive management. The study population included the administrative executive level.

\subsection{Study Sample}

The study sample consists of (38) managers working in the senior executive management and their assistants in the banks previously mentioned representing $100 \%$ of the total employees in the executive management and their assistants in the banks mentioned in the north of Jordan.

\section{Research Methodology}

The researcher adopted the descriptive, statistical, and analytical approach to achieve the objectives of the research, and validated its hypotheses based on two complementary types of the scientific research studies: the theoretical study and the field study. The theoretical study depended on collecting the theoretical scientific material from the previous books, researches and journals on the subject of the emotional intelligence. The field study of the sample is represented with the employees in the senior executive departments in the operating banks in the north of Jordan: the Islamic Bank, the Arab Bank, Al Rajhi Bank, the Bank of Jordan and Cairo Amman Bank.

\subsection{Data analysis Methods}

data were analyzed according to some statistical methods appropriate to the nature of the research, including the SPSS, through which were used the simple and multi regression analysis to measure the impact of a number of independent variables (the impact of the emotional intelligence) on the dependent variable (decision-making), Pearson correlation method to measure the strength and direction of the relationship between each variable of the independent variables with each variable from the dependent variables, chi-square to identify the statistical significance between the different study variables as well as other methods that are commensurate with the nature of the study, such as calculating the relative weights and frequencies. 


\section{Previous Studies}

1. (Al-Menkash, 2007) entitled with: "leadership over the group and leadership with the group: a comparative study between the two leadership styles of the males and females at King Saud University in Riyadh" which aimed to identify the impact of the sex factor on the leadership style of males and females. To achieve this goal, Vedler scale was sued to determine the extent of the males and females' practice of the leadership styles above the group and the leadership with the group. The study was applied to a sample of the academic heads of departments and directors at King Saud University in Riyadh. The most prominent results of the study are as follows: There were statistically significant differences between the males and females in practicing the two styles of leadership: above the group and with the group that the type of sex has a significant impact on the leadership style practiced, the vast majority of the males' (the heads of the academic departments) practice the leadership style with the group, the females' ( the academic departments directors) practice the leadership style over and with the group but the females' ratio of practicing the leadership style with the group exceed those practicing the other style, and finally there were no statistically significant differences between the leadership styles of the males and females attributed to the different specialization, academic rank or years of experience.

2. (Walter and Brush, 2007) entitled with "the role of the positive mood and the emotional intelligence of the leader" aimed to explore the role of the positive mood and the emotional intelligence of the leader in developing the leadership behavior and it was conducted on 34 leaders and 16 followers through multinational companies. The results showed that the positive mood and the emotional intelligence of the leader are positively associated with the leadership behavior and fellowship, the emotional intelligence of the leader modifies the relationship between the positive mood of the leader and his leadership behavior and finally the leaders with the high emotional intelligence show the highest leadership behaviors apart from the positive mood unlike those leaders with low emotional intelligence who showed leadership behaviors when their positive mood was only high.

3. (Sinj, 2007) entitled with "the emotional intelligence and the organizational leadership: A Study in light of the variable of sex" aimed to identify the relationship between the emotional intelligence and the organizational leadership and the effect of the emotional intelligence on the effectiveness of leadership in a computer software company in India; the study sample consisted of 210 males and 130 females of computer software professionals and the results indicated that there were no significant, positive relations between the emotional intelligence and the organizational leadership for both sexes, and that the emotional intelligence of the computer software designers contribute to the varying effectiveness of their own leadership.

4. (Morehouse, 2007) entitled with "exploring the emotional intelligence through the field of employment" aimed to identify the degrees of the emotional intelligence of leaders in the non-profit fields of work such as health services and humanitarian services along with the profit fields of work; the study sample consisted of 32 participants per group and the Bar-On intelligence scale was used. The results of the study showed that there were significant differences between the leaders of the profit and non-profit groups in the emotional 
intelligence, efficiency in managing pressures and adaptation; this means a different degree of leaders' emotional intelligence according to the field of work.

5-(Care, Garvin, Heeten and Boyle, 2006) entitled with "the emotional intelligence and the effectiveness of leadership" aimed to explore the relationship between the levels of the emotional intelligence and the classification of the leadership effectiveness through classifying the subordinates and the study sample consisted of 38 supervisors in different industrial companies; Meyer and Salovy test of emotional intelligence was used and the effectiveness of the leadership of supervisors were also determined from estimating their performance by the subordinates. The results showed a correlation between the degrees of the emotional intelligence and the obtained appreciation for the effectiveness of leadership indicating that the emotional intelligence is a strong indicator of the effectiveness of leadership.

6. (Dawnie, Papagergy, and stooge, 2006), which is entitled with "the relationship between leadership, emotional intelligence and intuition among a sample of female managers" aimed to assess the relationship between the leadership style, the emotional intelligence and intuition among a sample of females managers consisting of 176 female managers of various factories in Australia, who answered a tests' battery that consisted of a test of emotional intelligence, the public mood scale, and a referendum on the leadership styles and the results showed that the women who demonstrated leadership behaviors were more emotionally and intuitively intelligent.

7- (Higgs and Aitkin, 2003), which is entitled with "exploring the relationship between the emotional intelligence and the leadership behavior" aimed to explore the importance of the emotional intelligence as a predicator of the leadership potential; the study was conducted in the leaders' development center in New Zealand center and the study sample consisted of 40 managers working in the public service center who answered the emotional intelligence scale and the results showed that there is a relationship between the emotional intelligence and the leadership potential.

8- (Docket and Makavarln, 2003) entitled with " the emotional intelligence and the leadership in the field of retail sales" aimed to explore the relationship between the emotional intelligence and the leadership in the retail sales institutions in the UK and identify if there was a relationship between the performance of the store manager and the degree of his emotional intelligence through drawing a personal profile for the success of the leader through his subordinates; the results showed a strong correlation between the emotional intelligence of the store manager and his ability of a perfect leadership.

9-(Mandal and Ferwany, 2003), which is entitled with "the relationship between the emotional intelligence and the leadership style: a study in light of the variable of sex" aimed to explore the predictive relationship between the emotional intelligence and the leadership style as well as the differences between males and females with regards to those variables; the study sample consisted of 100 males and 100 females who were assessed according to the Meyer and Salovy test of emotional intelligence and applying the test of the leadership pattern. The results showed the presence of a significant predictive relationship between the 
leadership style and the emotional intelligence; the more the emotional intelligence, the more the effectiveness of leadership, as well as the presence of significant differences between sex and emotional intelligence and between sex and leadership style.

10 (Susik and Maijerian, 1999) which is entitled with "understanding the emotional intelligence and the performance of the leader" aimed to explore if the self-consciousness of the director (which is defined as the harmony between the self and others) is to modify the relations between the manifestations of the emotional intelligence and the leadership behavior, and between the leadership behavior and the administrative performance. Data were gathered from 63 directors who answered the tests for measuring the emotional intelligence and the leadership behavior in addition to 192 subordinates who assessed the leadership behavior and the results of the performance of their heads of departments. The results showed that the relationship between the emotional intelligence and the leadership behavior varies which is an indicator of the self-awareness of the director.

\section{Theoretical Framework}

\subsection{Concept of Intelligence}

God says in the Holy Koran "And when they Lord said to the angels, I am going to place a ruler in the earth..."(Koran -AlBakarah, verse 30). This means that God created a successor on earth, the man, and He made him distinguished to the rest of the creatures through the mind making all creatures of animals, plants and things at his service so as to be God's successor on earth. God distinguished him with the mind, which is the center of intelligence. As for intelligence, it has several definitions.

Bin Mukaram defined it as the quick cleverness (Ben Mukaram, 2003, 1510)

Psychologists defined intelligence as the ability to cope up with new situations or learn to face new responses or the ability to do tasks, pass exams and understand the relationship between things; the more the complexity, the higher the intelligence ratio (Al-Obeidi and Al-Salim, 2012, 752).

Al-Abbadi defined intelligence as a set of core abilities and implied knowledge owned by the individual to be used in matters that cannot be handled by another individual (Al-Abbadi, 2012, 860). Mcdowell defined intelligence as a process of processing information through data processing before becoming understandable and useful information (McDowell, 2009, Pp. 11-12).

Herschel defined intelligence as the ability to think logically and make meaningful changes (Herschel, 2010) in effectively dealing with the targeted environment.

Intelligence is the administration reservoir in facilitating the speed of understanding due to the importance of linking the administration with leadership and spreading the logic that the leadership cannot lead to results without an administration and that the administration cannot lead to results without leadership (Marcom, 2002).

Intelligence leads to smartness in achieving success; this is shown in a study conducted by 
Robert Half US Foundation regarding the information on the affecting factors and elements on selecting the administrative leaders which found out that the highest rates was for the element of intelligence (Saleh et al., 2010, 111-112).

In the field of the administration association with intelligence, intelligence is defined as a process designed to support business decisions in the fields of marketing and finance and determine the trends of the market and the competing customers to get a market share, new customers and exceed competitors. Another term which is associated with intelligence is organization known as the organizational intelligence, which is the main ingredient in the success of the organization and achievement of its objectives; smart organizations get, analyze and benefit from information (Stenberg, 2009).

The organizational intelligence is defined as all the possibilities and potential in the organization by which the business mentality is employed which helps in breaking down the strategic and automatic routines as well as the rest of the regulatory frameworks; each employee that can develop an intellectually conceptual concept of the organization is part of its intelligence

(Al-Ta'ie and Dham, 2008, 76).

The organizational intelligence is defined as the procedural capacity of the organization to effectively manage its operations, which is all the knowledge and skills in both the tangible and intangible assets available to cooperate in solving problems and making decisions within the organization. (Jung, 2009, 45).

Al-Abbadi states that there are three levels of the organizational intelligence: strategic, tactical and operational (Al-Abbadi, 2012, 862).

The operational intelligence is concerned with running the daily business and it is used by business managers and operational systems and it is based on daily data; the tactical intelligence, on the other hand, seeks to achieve strategic targets and it is used by the directors of the operations departments and business analysts with a time frame from a day to a year and its data are considered historic, and finally the strategic intelligence which focuses on long-term goals and it is used by the executive directors of the senior managements and its time frame ranges from a month to a year or more (Hijazin, 2015,45).

The emotional intelligence is considered one of the important topics in the fields of business and social life in general. It consists of a modern term though it is practiced since the beginning of creation. God has created man with an instinct and mind representing the needs and behavior traits, characteristics and features of what we call the emotional intelligence.

Goleman defined the emotional intelligence as the individual's ability in the emotional reading i.e. reading the feelings of others so that good social relations are shaped. It also includes self-control and the feelings and desires' control; it also able to be learned. (Goleman, 1998).

Al-Safarini defined the emotional intelligence as the human's ability to positively deal with himself and the positive interaction with others or it is the ability of self-control through 
controlling the emotions (Al-Safarini, 2006, p.).

The emotional intelligence combines the mental and the emotional sides of the individual; it includes the ability to accurately perceive, asses and express emotions and the ability to generate emotions or access them when the thinking process is on the go. It also means the ability to understand emotions and the emotional knowledge and the ability to regulate emotions so as to promote the emotional and mental development (Al-Khadir, 2006, p. 12).

The emotional intelligence develops the individual's ability in facing the difficulties during the job. This ability gives the individual joy, happiness and satisfaction for him and others. If those in the senior and middle management could read their feelings, they can control them. Those who possess and use the emotional intelligence in his work would have the art of dealing with feelings and emotions putting away some psychological inclinations to reach to common things with others who work with him, whether they are subordinates or those with the same authority. God ordered us to be compassionate, cooperative, generous and merciful so that love fills all hearts and the good is spread everywhere.

The emotional intelligence is also defined as the individual's ability to manage, control and choose the best emotions that fit with the positions facing the human (Muhammad, 2014, 59). Among the most famous with regards to this term is Daniel Guttman, who defined the emotional intelligence as the individual's ability to fully know his emotions as well as those of others, so that this person can handle himself first then can handle others through moving between his emotions and expressing his emotions in a way that is appropriate to the situation and case where he is present.

Guttman defined it as exploring the emotions, controlling the tendencies, postponing gratification, overcoming frustration, being involved emotionally, having good relations with others and stimulating the self in an optimistic and confident method (Gottman, 2002.). Marttinez defined the emotional intelligence as a daily subjective process practiced by the individual and it includes motivation, planning, goal, using different tactics and strategies, self-assessment, establishing successful relationships with others, the ability of the individual to confront problems, the ability of self-control and the control of emotions. (Marttinez, 2000).

Thuraya Al-Sayyid Ahmad defined it as the individual's realization of emotions and feelings, his ability to control emotions, and the way to deal with the feelings of others in holding successful and positive human relations with others (Ahmad, 2003, p 473-532).

It is widely known that the emotional intelligence is the foundation of success in life that the ordinary intelligence, which is measured by what is known as the (IQ) tests is different from the emotional intelligence; those who suffer from the emotional disorders might have powerful mentality and high levels of intelligence but they cannot interact with others nor know their feelings and how to manage the crises they face. We conclude that the emotional intelligence is the road to reach goals and objectives especially when it comes to the leadership positions that require an interaction with a large number of people. Some attributes that are evident in those who enjoy a high degree of emotional intelligence is the ability to 
understand the situations and conditions of others, be sympathetic with them when being in trouble, form multiple friendships, resolve disputes and differences between them and others or those that occur between other people themselves, express their feelings even if they were mixed, face problems with high confidence, and adapt to all the social situations; finally, the people who have an emotional intelligence are inclined to independence in opinion and they try to understand things. An emergence from the emotional intelligence is what is known as the social intelligence, which is the individual's ability to manage his relations with others by understanding the situation or putting himself in place of others so he can be able to assess the emotions he had in that position. It should be noted that the body language and movements of people during a conversation are one of the most important factors that lead to an increase in getting closer to others and affecting them leading to increasing their emotional intelligence.

The researcher believes that the emotional intelligence is the individual's ability to understand himself, his emotions and feelings and motivate others. It can be described as the skills of identifying our self-feelings as well as those of others to control our emotions and hold better relations with all employees in their different positions and levels.

Thinkers agree that the emotional intelligence is the basis of the success of the life and the success of organizations in reaching their goals due to the fact that using emotions in decision-making will lead to easier implementation. If leaders, administrators and decision-makers possess the emotional intelligence, they will interact honestly with others .when the leader, decision-makers and administrators assess the feelings personally, they get to know what feelings are.

Goleman divided the dimensions of emotional intelligence into six dimensions, namely, (Hassouna and Abu Nashi, 2006, pp. 58-63)

Self-awareness: the awareness of our emotions and feelings and awareness of the thoughts associated with these emotions and the constant attention of the internal, personal case, which is the basis of the psychological insight and self-confidence and we are in a constant state of getting to know our strength.

Self-awareness has a strong impact on negative emotions. It is represented in the ability of those in charge to identify and understand the personal feelings and the things that motivate us and their impact on others. The attributes also include self-confidence, and objectivity in assessing your abilities.

2-processing the emotional aspects in general. Knowing how to handle or deal with the emotions that hurt and bother us due to the fact that this treatment is the basis of the emotional intelligence. It also means the ability to withstand the stormy emotions of life, the feeling that you are the master of yourself, and achieving balance in dealing with matters of life. Every emotion has its value and importance and without passion, life becomes stagnant, boring and isolated from the richness of life itself. Furthermore, the key to an emotional health is our observation of negative feelings, and the emotional extremism leads to the loss of the personal balance of people. 
3-motivation:

It means having a certain goal, knowing our steps, having the enthusiasm and perseverance for continuing the pursuit, and hope, which is an essential component of motivation, and teaching our children to have hope, positive feelings and motivations that mobilize humans' energy for achievement such as enthusiasm, perseverance and confidence.

4-understanding:

It means reading and identifying the feelings of others as well as responding to them through their voices or facial expressions; knowing the feelings of others is a main human ability while the failure to recognize the feelings of others is a main deficit in the emotional intelligence, which is considered a failure in the humanity of humans.

Understanding is built on self-awareness. Each intimate relation stems from the ability to be companionate and caring; it has a key role in various aspects of life.

5-social skills:

It means the ability to read and understand the social behavior and the skill of social participation, such as the verbal and emotional expression, and reading over playing the social role efficiently and the ability to build and manage social relationships effectively. It includes some of the key characteristics of: the ability of leading the change effectively, building and leading the team, and the ability of persuading.

6. Empathy: through empathy, people have a knowledge perspective about the other person. It is affected with the logical trend of individuals. People who are characterized by empathy are more able to make decisions in a timely manner.

The emotional intelligence is one of the key variables which became prominent as one of the essential qualities of the effective administrative leadership. The emotional intelligence is described as a set of capabilities which relates to the individual's ability to deal with his feelings and emotions as well as his ability to deal with the feelings of others.

With regards to leadership, the ability to deal with emotions and feelings can contribute to dealing with the needs of individuals and the way of motivating them effectively. The leader who enjoys the emotional intelligence is believed to be more loyal and committed to the organization where he works (Abraham, 2000), has a better work performance (Goleman1998), able to use his intelligence to improve and increase the level of decision-making, and finally able to add happiness, joy, confidence and cooperation among his employees through his personal relationship (George, 2000).

The effectiveness of leadership refers to the administrative leadership's ability to achieve certain goals through using the available resources. Hureya defines it as the ability degree of the leader to achieve the goals of his administration with the available human, physical and temporal resources in addition to the resources within the framework of the public policies set (Hurreya, 2013, 413). The effective leadership works carefully to choose the right direction for change (Hijazin, 2015, 76). The effective leadership is defined as clarifying the path to 
help the followers to achieve their goals and facilitating the path through reducing barriers and pitfalls (Uddin, Alam, K2014, 697).

The effectiveness of leadership is not limited to increasing the production and achieving the productivity goals, but it extends to achieving satisfaction, conviction and lifting the morale of the personnel; it examines the renovation and growth they feel, revitalize and revive the motives and efforts found within individuals and enable them to use them to achieve goals.

(Al-Qahtani, 2006, 29).

The effectiveness of the leadership is based on the extent of achieving goals. Since we consider that leadership is not an individual but a group of individuals in administrative positions, we must take into account the leadership pattern followed by the administrative leaders and their followers. Does the administrative leadership, through its leadership administrative pattern, achieve the job satisfaction for the followers creating for them a job loyalty and motivation.

The effectiveness of leadership is the outcome of the activity of both the leader and the subordinates to achieve the goals at work (Ben Jami', 2010, 81). The effective leader creates an atmosphere of teamwork that makes the individuals within the organization exceed all the obstacles they face in order to achieve the best possible results (Khababah, 2012,21). The effective leader balances the needs of the organization through taking care of the job, results and the needs of employees through satisfying their needs giving them a job satisfaction; therefore, the effective leadership pattern shows a high interest in both the production and individuals alike (Al-Omyan, 2010,275).

\section{Field Study and Statistical Analysis}

\subsection{The Study Population and Sample}

The study population is focused on the employees in the administration of the banks working in the northern of Jordan amounting to (250) from different functional levels. However, the study sample represented all the employees in the senior management and their assistants amounting to (38) managers and assistants from the study population. The questionnaires were distributed to all the members of the sample then they were collected and returned after fully filling them due to the great care and follow up of researchers with a ratio of $(100 \%)$ of the size of the questionnaires that were distributed to the members of the sample.

\subsection{Data Collection Methods}

The method of collecting data adopted by the researcher which was represented in adopting the secondary sources, whether books, references, periodicals or official documents and relying on the traditional and electronic library. The other method is represented in the primary sources, which are represented in the questionnaire.

\subsection{Variables and Scales}

The study tool, the questionnaire, consists of two parts: 
- The first part included the personal information about the respondents and it consists of the questions of the questionnaire (1-3) in the first part of the questionnaire questions.

The second part: it includes the questions related to the job trends in the internal regulatory environment of the surveyed organization to identify the levels of the emotional intelligence in the departments concerned. They are included in the questions of the questionnaire (1-23); each paragraph has a number of items under four axes to measure the level of using the emotional intelligence for the study sample. The researcher has adopted the quintet Likert scale to measure the approval degree of the members of the sample as it is shown in Table 1 below:

Table (1) the Quintet Likert scale

\begin{tabular}{|l|l|l||}
\hline No & Acceptance degree & relative importance \\
\hline $\mathbf{1}$ & Strongly disagree & One degree \\
\hline 2 & agree & Two degrees \\
\hline 3 & neutral & three degrees \\
\hline 4 & Somehow agree & four degrees \\
\hline 5 & Strongly agree & five degrees \\
\hline
\end{tabular}

The total number of the degrees of the Likert scale is (15) degrees and the arithmetic mean is (3) degrees, representing $(60 \%)$ of the Likert scale; the researcher will depend on this scale in testing the hypotheses so that the effect becomes acceptable when it reaches (3) or more since they included some questions that cover all the study axes so as to be answered from the selected sample.

\subsection{Testing the Sincerity and Reliability of the Study Tool}

The reliability of the tool was tested through the Cronbach's alpha coefficient. Looking at Table (1), we find that:

1. The Alpha value of the dimension of the self-awareness is 0.78

2. The Alpha value of the dimension of the self-control is 0.76

3. The Alpha value of the dimension of the emotional balance is 0.81

4. The Alpha value of the dimension of the democratic style is 0.84

5. The Alpha value for all the items is 0.87

All of these values are greater than 0.60 ; therefore, there is a reliability in the study tool. 


\section{Macrothink

Table (2): Cronbach's alpha test results:

\begin{tabular}{|l|l|}
\hline dimension & Alpha value \\
\hline Self-awareness & $\mathbf{0 . 7 8}$ \\
\hline Self-control & $\mathbf{0 . 7 6}$ \\
\hline Emotional Balance & $\mathbf{0 . 8 1}$ \\
\hline Democratic Style & $\mathbf{0 . 8 4}$ \\
\hline total & $\mathbf{0 . 8 7}$ \\
\hline
\end{tabular}

\subsection{The Statistical Methods Used}

The researchers have relied on the descriptive statistics to analyze the content and present the statistical data such as the frequencies, percentages, arithmetic mean and standard deviation, as well as the inferential statistical method to get various differences, where the researchers used the $\mathrm{T}$ Test for the independent samples and the ONE WAY ANOVA.

\section{Testing Hypotheses}

The first hypothesis: there is a relationship between the self-awareness (self-realization) and the effectiveness of leadership in decision-making

Table (2) shows that all the items have got arithmetic means greater than 3.00 and the significant level of observation is less than 0.05 , so they have a statistical significance. Item 3 which measure the leaders' extent of showing enthusiasm in their dealings with employees in the first rank by an arithmetic mean of 4.43 followed by item No. 2, 5 and 4, respectively. Item 1 which measures the leaders' extent of exceeding all the problems that happened in the past in the last rank with an arithmetic mean of 3.39 .

All items have obtained an arithmetic mean greater than 3.00 and the observation's significant level is less than 0.05; therefore, it is statistically significant. Accordingly, the first hypothesis is accepted since there is a relationship between self-awareness (self-realization) and the effectiveness of leadership in decision-making. 


\section{Ml Macrothink}

International Journal of Human Resource Studies

ISSN 2162-3058 2016, Vol. 6, No. 4

Table (2): Arithmetic means, standard deviations, $\mathrm{T}$ value, and the significant level of observation of the self-awareness:

\begin{tabular}{|c|c|c|c|c|c|}
\hline $\begin{array}{l}\text { Item } \\
\text { No. }\end{array}$ & item & $\begin{array}{l}\text { Arithmatic } \\
\text { mean }\end{array}$ & $\begin{array}{l}\text { Standard } \\
\text { deviation }\end{array}$ & $\begin{array}{l}\text { T } \\
\text { value }\end{array}$ & $\begin{array}{l}\text { the significant } \\
\text { level of } \\
\text { observation }\end{array}$ \\
\hline 1 & $\begin{array}{l}\text { I exceed all the problems that } \\
\text { happened to me in the past }\end{array}$ & 3.39 & 1.07 & 3.65 & 0.00 \\
\hline 2 & $\begin{array}{l}\text { I can identify the feelings of } \\
\text { the others towards me }\end{array}$ & 4.03 & 0.89 & 10.25 & 0.00 \\
\hline 3 & $\begin{array}{l}\text { I show enthusiasm in my } \\
\text { dealings with employees }\end{array}$ & 4.43 & 0.73 & 19.15 & 0.00 \\
\hline 4 & $\begin{array}{l}\text { I have a desire to make } \\
\text { friends with employees }\end{array}$ & 3.68 & 1.04 & 8.20 & 0.00 \\
\hline 5 & $\begin{array}{l}\text { I deal objectively with all the } \\
\text { issues in the organization }\end{array}$ & 3.95 & 0.68 & 8.99 & 0.00 \\
\hline total & & 3.90 & 0.87 & 20.15 & 0.00 \\
\hline
\end{tabular}

The second hypothesis: there is a relationship between self-control and the effectiveness of leadership in decision-making

Table (3) shows that all the items have obtained arithmetic means greater than 3.00 and the observation's significant level is less than 0.05 so they are statistically significant. item No. 7 which measures the leaders' extent of lack of fear from talking in meetings came in the first rank with an arithmetic mean of 4.65, followed by item No. 11, 12, 10, 8, 9, respectively. Item 6 which measure the extent of rationing the openness of leaders to employees to keep calm came in the last rank with an arithmetic mean of 3.97.

All items have obtained an arithmetic mean greater than 3.00 and the observation's significant level less than 0.05 meaning that they are statistically significant; accordingly, the second hypothesis was accepted where there is a relationship between self-control and the effectiveness of leadership in decision-making. 


\section{Macrothink}

International Journal of Human Resource Studies

ISSN 2162-3058

2016, Vol. 6, No. 4

Table (3): Arithmetic means, standard deviations, $\mathrm{T}$ value, and the significant level of observation of the self-control:

\begin{tabular}{|c|c|c|c|c|c|}
\hline $\begin{array}{l}\text { Item } \\
\text { No. }\end{array}$ & item & $\begin{array}{l}\text { Arithmatic } \\
\text { mean }\end{array}$ & $\begin{array}{l}\text { Standard } \\
\text { deviation }\end{array}$ & $\begin{array}{l}\text { T } \\
\text { value }\end{array}$ & $\begin{array}{l}\text { the } \\
\text { significant } \\
\text { level of } \\
\text { observation }\end{array}$ \\
\hline 6 & $\begin{array}{l}\text { my openness to employees is } \\
\text { codified to keep my calm }\end{array}$ & 3.97 & 1.017 & 6.56 & 0.00 \\
\hline 7 & $\begin{array}{l}\text { I feel afraid of talking in } \\
\text { meetings }\end{array}$ & 4.65 & 0.777 & 23.16 & 0.00 \\
\hline 8 & $\begin{array}{l}\text { I feel angry when being } \\
\text { criticized by any employee }\end{array}$ & 4.2 & 0.987 & 10.45 & 0.00 \\
\hline 9 & $\begin{array}{l}\text { I involve my emotions and } \\
\text { feelings when having a } \\
\text { discussion with any of the } \\
\text { employees }\end{array}$ & 4.17 & 1.017 & 9.75 & 0.00 \\
\hline 10 & $\begin{array}{l}\text { My anger becomes evident } \\
\text { when having a discussion with } \\
\text { any employee }\end{array}$ & 4.25 & 1.097 & 10.33 & 0.00 \\
\hline 11 & $\begin{array}{l}\text { I let others feel my friendship } \\
\text { while talking with them }\end{array}$ & 4.42 & 1.237 & 11.6 & 0.00 \\
\hline 12 & $\begin{array}{l}\text { I listen well and I do not } \\
\text { interrupt others }\end{array}$ & 4.36 & 0.967 & 13.41 & 0.00 \\
\hline Total & & 4.29 & 0.70 & 14.04 & 0.00 \\
\hline
\end{tabular}

The third hypothesis: there is a relationship between the emotional balance and the effectiveness of leadership in decision-making.

Table (4) shows that all items have obtained arithmetic means greater than 3.00 and significant levels of observation less than 0.05 , so they are statistically significant. Item 16 which measure the leaders' extent of enjoying flexibility in dealing with problems have ranked first with an arithmetic mean of 4.18 followed by items 15 and 13. Item No. 14, which measures the leaders' extent of sitting in quiet and contemplative sessions came in the last rank with a mean of 3.67. 


\section{Ml Macrothink}

All items have obtained an arithmetic mean greater than 3.00 and the significant level of observation less than 0.05 meaning that they are statistically significant; accordingly, the third hypothesis was accepted where there is a relationship between the emotional balance and the effectiveness of leadership in decision-making.

Table 4: Arithmetic means, standard deviations, $\mathrm{T}$ value, and the significant level of observation of the emotional balance:

\begin{tabular}{|c|c|c|c|c|c|}
\hline $\begin{array}{l}\text { Item } \\
\text { No. }\end{array}$ & item & $\begin{array}{l}\text { Arithmatic } \\
\text { mean }\end{array}$ & $\begin{array}{l}\text { Standard } \\
\text { deviation }\end{array}$ & $\begin{array}{l}\mathrm{T} \\
\text { value }\end{array}$ & $\begin{array}{l}\text { the } \\
\text { significant } \\
\text { level of } \\
\text { observation }\end{array}$ \\
\hline 13 & $\begin{array}{l}\text { I hold myself responsible after } \\
\text { every argument with any of the } \\
\text { employees }\end{array}$ & 3.76 & 1.03 & 7.98 & 0.00 \\
\hline 14 & $\begin{array}{l}\text { After work, I sit in quiet and } \\
\text { contemplative sessions }\end{array}$ & 3.67 & 1.17 & 5.24 & 0.00 \\
\hline 15 & I can solve problems quietly & 3.9 & 1.28 & 8.80 & 0.00 \\
\hline 16 & $\begin{array}{l}\text { I enjoy flexibility in my dealings } \\
\text { with the problems }\end{array}$ & 4.18 & 0.68 & 16.23 & 0.00 \\
\hline $\begin{array}{l}\text { Tota } \\
1\end{array}$ & & 3.88 & 0.95 & 13.28 & 0.00 \\
\hline
\end{tabular}

Fourth hypothesis: there is a relationship between adopting the democratic style and the effectiveness of leadership in decision-making

Table (5) shows that all the items have obtained arithmetic means greater than 3.00 and the significant level of observation was less than 0.05 meaning that they are statistically significant; Item 22 which measures the employees' extent of holding the responsibility of the wrong decision came in the first rank with an arithmetic mean of 4.40 followed by items 20 , $21,17,18$, and 23 respectively. Item 19 which measures the extent of involving the employees in making decisions came in the last rank with a mean of 3.74 .

All items have obtained an arithmetic mean greater than 3.00 and the significant level of observation less than 0.05 meaning that they are statistically significant; accordingly, the fourth hypothesis was accepted where there is a relationship between adopting the democratic style and the effectiveness of leadership in decision-making. 
Table (5): Arithmetic means, standard deviations, $T$ value, and the significant level of observation of anger:

\begin{tabular}{|c|c|c|c|c|c|}
\hline $\begin{array}{l}\text { Item } \\
\text { No. }\end{array}$ & item & $\begin{array}{l}\text { Arithmatic } \\
\text { mean }\end{array}$ & $\begin{array}{l}\text { Standard } \\
\text { deviation }\end{array}$ & $\begin{array}{l}\text { T } \\
\text { value }\end{array}$ & $\begin{array}{l}\text { the } \\
\text { significant } \\
\text { level of } \\
\text { observation }\end{array}$ \\
\hline 17 & $\begin{array}{l}\text { I do not allow others to } \\
\text { participate in the traditional } \\
\text { decisions }\end{array}$ & 3.90 & 1.22 & 8.27 & 0.00 \\
\hline 18 & $\begin{array}{l}\text { I consult some employees when } \\
\text { making decisions }\end{array}$ & 3.84 & 0.95 & 10.08 & 0.00 \\
\hline 19 & $\begin{array}{l}\text { I involve employees in making } \\
\text { decisions }\end{array}$ & 3.74 & 0.99 & 8.07 & 0.00 \\
\hline 20 & $\begin{array}{l}\text { I collect data and information } \\
\text { before making decisions }\end{array}$ & 4.37 & 1.69 & 10.11 & 0.00 \\
\hline-21 & $\begin{array}{l}\text { I authorize some of the } \\
\text { employees to make decisions }\end{array}$ & 3.93 & 1.02 & 9.56 & 0.00 \\
\hline-22 & $\begin{array}{l}\text { I hold the employees the } \\
\text { responsibility of the wrong } \\
\text { decisions. }\end{array}$ & 4.40 & 0.86 & 13.82 & 0.00 \\
\hline-23 & $\begin{array}{l}\text { I employ feelings when trying to } \\
\text { convince others of decisions }\end{array}$ & 3.77 & 0.79 & 18.31 & 0.00 \\
\hline Total & & 3.99 & 1.20 & 13.29 & 0.00 \\
\hline
\end{tabular}

\section{Results}

After the researcher had conducted the statistical analysis of the respondents' answers to the questionnaire, he reached to the following results:

1. there is a relationship between self-awareness (self-realization) and the effectiveness of leadership in decision-making, where the leaders exceed all the problems that happened to them in the past, become able to identify the feelings of others towards them, show enthusiasm in their dealings with employees, have a desire to make friends with them, and objectively deal with all the issues in the organization. 
2. there is a relationship between self-control and the effectiveness of leadership in decision-making, where leaders are open to employees in a codified manner in order to keep calm; they feel scared of talking in meetings, do not feel angry at being criticized by any employee, involve their emotions and feelings when having a discussion with any of the employees, show their anger during a discussion with one of the employees, let others feel they are liked while talking to them, and finally listen will and do not interrupt others.

3 - There is a relationship between the emotional balance and the effectiveness of leadership in decision-making, where leaders hold themselves responsible after each argument with one of the employees, sit in quiet and contemplative sessions after work, able to solve problems quietly, and are characterized by flexibility in dealing with their problems.

4. there is a relationship between adopting the democratic style and the effectiveness of leadership in decision-making, where leaders do not let others participate in the traditional decisions, consult some employees when making decisions, involve employees in making decisions, collect data and information before making decisions, delegate some employees in making decisions, hold employees the responsibility for the wrong decision, and employ emotions when trying to convince others with the decision.

\section{Recommendations}

1. The study recommends holding programs to develop the leadership's ability in strengthening the sense of the self-awareness of managers and other workers in the field of decision-making and the importance that leaders exceed all the previous events that may adversely affect the work of the organization not making them negatively affect them when making decisions or dealing with the employees.

2. The study calls leaders and managers to control themselves when dealing with the employees not making anger control them which leads to hasty decisions as a result of anger or instability. They should choose the right and convenient time for them to study the alternatives and select the appropriate alternative to achieve the organization's goals and the objectives of the employees away from all the negative interactions.

3-the study called for employees in management and decision-making in the surveyed organizations to hold quiet sessions after work to review their work and their relationships with the executive employees; the process of holding responsibility is one of the best means to verify and activate the emotional intelligence among employees in the organization, especially the decisions issued along with the problems they faced and review the results of solutions.

4-the study recommends organizations to prepare training programs to develop the emotional intelligence for all the employees of the surveyed organization and make the emotional intelligence a part of the culture of the organization so that the managers become role models for other employees.

5-the study recommends adopting the democratic style in management to remove the physical and moral barriers between managers and other employees, involving employees in decision-making and meeting all their needs and desires, and increasing the social gatherings 
among all employees outside of work, such as concerts, seminars and trips so that employees get closer to each other and love and satisfaction are strengthened.

6-the study calls researchers to have interests and write on the subject of emotional intelligence due to its significant role in raising the morale, achieving the satisfaction of employees and fulfilling the organization's goals.

\section{Arabic References}

Ahmed, Al-Sayyid Ali Ahmad -2003- the Emotional Intelligence and its Relationship to the Psychological Adjustment and the Self-control, Journal of Scientific Approach and Behavior, Part II, second issue, January, Cairo, Egypt

Al-Haj, Sana, 2012, Emotional Intelligence and Building Humans -April - Researches and Studies

Al-Haj, Mohammad Mohammad -2014 What Emotional Intelligence is?

Al-Khader, Othman Mahmoud -Emotional Intelligence -2006 the Intellectual Creativity Company for Publishing and Distribution - Kuwait 4

Al-Taie, Ali Hassoun and Dham, Ala'a -2008-the Impact of the Emotional Intelligence on the Organizational Intelligence- Journal of Economic and Administrative Sciences 14 (52) University of Baghdad - Iraq

Al-Abadi, Hashem Fawzi, 2012, the Organizational Intelligence as a Business Organization towards Building a Smart Organization -Conceptual Perspective, Faculty of Economics and Administrative Sciences, University of Al-Zaytuna-Amman - Jordan

Al-Obeidi, Mohammed Abd AlAziz and Al-Salem, Qusai Salem, 2012 the Strategic Intelligence to Support the Audit Quality, A Prospective Study - Proceedings of the Eleventh Annual Scientific Conference, Faculty of Economics and Administrative Sciences, University of Al-Zaytuna-Amman - Jordan

Al-Omyan, Mahmoud Salman, 2010. The Organizational Behavior in Business Organizations-Jordan - Amman, Wael House for Publishing and Distribution.

Al-Qahtani, Ahmad bin Yahia Mohammad, 2006, Ways of Improving the Effectiveness of the Field Leadership in the Border Guard Center - Master Thesis in Police Sciences - Naif Arab University for Security Sciences - Riyadh - Saudi Arabia.

Al-Massad, Mahmoud, the Effective Administration, 2003 Lebanon Library, Publishers, Beirut, p. 127

Al-Mankash, Sarah bent Abdullah Saad, 2007: Leadership Above the Group and Leadership with the Group: A Comparative Study between the Leadership Style of Males and Females at King Saud University in Riyadh -Journal of the Education and Psychology Message - Issue 28. 
Ben Jami', Ibrahim, 2010. The Emotional Intelligence and its Relationship with the Effective Leadership - Master Thesis - Mentouri University - Constantine - Algeria

Ben Makram, Abou Al-Fadel Jamal Al-Din Mohammed (Bin Manthur) 2003, the Language of the Arab (Lesan Al-Arab), Lebanon, Beirut,13.

Ahmad, Thuraya Al-Sayyid Ahmad, 2003, the Emotional Intelligence and its Relationship with the Psychological Adjustment and Self-Control, Journal of the Scientific Method and Behavior - Part II of the second issue, January, the psychological counselors Association, Nadab, Tanta - Egypt

Hassunah, Amal Mohammad and Nashi, Mona Said -2006 Emotional Intelligence V.1, Al-Dar Al-Elmia for publication and distribution, Cairo, Egypt.

Hurreya, Ali Hussein -2013-the Effectiveness of the Administrative Leadership among the Male and Female Managers of the Public Schools of the Directorate of Education in Medina, Educational Sciences Studies, 40, King Saud University, Riyadh - Saudi Arabia.

Khababa, Hassan, 2012, the Effect of the Leadership Styles in the Organizations on the Performance of Individuals - Journal of Banking and Financial Studies 19 (2) University of Jordan-Amman - Jordan.

Sally Ali, Hasan,2007, the Emotional Intelligence of the Kindergarten Teachers, AlMarefa AlJami'iya house of publication, Alexandria, p 40

Sinj, 2007 Intelligence and Leadership, PHD Thesis of Yumna Salah Ahmad Shahib - Tanta University - Egypt, 2007

PHD Thesis of Yumna Salah Ahmad Shahib , leader's Performance

Susik and Mijreyan, 1999 Understanding the Emotional Intelligence, Tanta University, Egypt

Al-Safarini, Iyad, 2006 the Emotional Intelligence - AlAwa'il House for Publishing and Distribution ,V.a, Damascus, Syria

Saleh, Ahmad Ali and Al-Azzawi, Bushra Hashim and Ibrahim, Khalil Ibrahim, 2010, Administration with Intelligence, an Approach of the Strategic and Social Excellence of Organizations - Jordan-Amman - Wa'il House of Publication.

Mohammad Mohammad, What Emotional Intelligence is? 2014- Last update: 06:59, August 31.

Shahib, Yumna Salah Ahmad, 2007, Discovering the Relation between the Emotional Intelligence and the Leadership Behavior, 2003 , PHD Thesis for the student Yumna Salah Ahmad Shahib, Tanta University - Egypt

Docket and Makvarln, 2003, the Emotional Intelligence and Leadership in the Retail Sales, PhD Thesis for the student Yumna Salah Ahmad Shahib - 18/8 /2007- Tanta University Egypt.

Mandal and Ferwani, 2003, the Relationship between the Emotional Intelligence and 


\section{Macrothink}

International Journal of Human Resource Studies

ISSN 2162-3058

2016, Vol. 6, No. 4

Leadership Style. PhD Thesis for the Student Yumna Salah Ahmad Shahib - 18/8 /2007Tanta University - Egypt.

Marcom, Dave -Smith, Steve, Wakalsa Mahan, 2002, the Administrative Intelligence, issued by the Arab Company for the Scientific Media (Shua'a AlQahira, tenth year (15).

Kerr and Garvin, the Emotional Intelligence and Leadership Effectiveness, PhD Thesis by the student Yumna Salah Ahmad Shahib - 18/8 /2007- Tanta University - Egypt.

"Dawnie" and "Babagergy" and "stoge, 2006, the Relationship between the Leadership, the Emotional Intelligence and Intuition among a Sample of Managers)

Koran, the Book of God - Albaqara, Sura 30

\section{Foreign References}

Claude Louche, Psychologie sociale des organisations, Arman Colin, 2éd, Paris 2007, p115.

McDowell, Don 2009 strategic intelligence: A hcrow press, Incandbook for practitioners, Managers and users- United States Of America-Scare.

Goleman, D, 1998, Working with emotional intelligence, New York, Bontam, -Gottman, J.2002, Raising on Emotional Intelligent childin falanew, horizons, Org,

Herschel, Richard, 2010, What is business Intelligence, Originally published June, 1from Http // www.b-eye-twork.com / view / 13768.

Jung, younghan, 2009.an Approach to organizational intelligence Management (Aframewor; for Analyzing Organizational Intelligence within the construction Process, Degree Of Doctor Of philosophy, Virginia polytechnic Institute and state University.

Martinez, P.M.2000, -Emotional Intelligences self-Regulatory Process-Asocial cognitive view imagination cognition and personality, VOl. 19 (4) Pp.334-336.

Ryff, C.D (2001); Emotional social relationship and health, London Oxford University Press.

McDowell, Don 2009.Strategic Intelligence, A handbook for practitioners Managers And Users- united states of America Scarecrow press, Inc -Stenberg

Uddin, Mohammed Nashir -and Alam Muhammad Shafiul 2014.Effectiveness Of Leadership Behavior Among Academicians; a study At shahjalal University Of science and Technology -journal of emerging Trends of Educational Research and Policy Studies (JETERAPS) 5 (6) MISSN (2041-6990). 
Questionnaire

Brothers / Sisters working in the Jordan Islamic Bank

Greetings,

The researcher is conducting a practical field study on the employees in the bank entitled with:

The Impact of Using the Emotional Intelligence on the Effectiveness of the Leadership in Decision-Making

\section{An Empirical Study}

The researcher is kindly asking you to fill the questionnaire with accuracy and attention serving the purposes of scientific research to reach to the desired scientific results; this information will be treated as confidential and for the purposes of scientific research only. Thank you for your cooperation and response.

First: personal characteristics:

sex: O Male O Female

Experience: $\mathrm{O}$ less than 5 years $\mathrm{O}$ from 5 to less than 10 years $\mathrm{O}$ less than 10 years and more Educational Qualification: o- high school O diploma O Bachelor O Graduate

\begin{tabular}{|c|c|c|c|c|c|}
\hline $\mathrm{NO}$ & Item & $\begin{array}{l}\text { Strongly } \\
\text { agree }\end{array}$ & agree & Neuter & $\begin{array}{l}\text { Strongly } \\
\text { disagree }\end{array}$ \\
\hline \multicolumn{6}{|c|}{ self-realization } \\
\hline $1-$ & $\begin{array}{l}\text { I leave behind all problems that happened to } \\
\text { me in the past problems }\end{array}$ & & & & \\
\hline $2-$ & I can recognize how others feel towards me & & & & \\
\hline $3-$ & $\begin{array}{l}\text { I show enthusiasm while dealing with the } \\
\text { employees }\end{array}$ & & & & \\
\hline $4-$ & $\begin{array}{l}\text { I have a desire in making friends with } \\
\text { employees }\end{array}$ & & & & \\
\hline $5-$ & $\begin{array}{l}\text { I deal objectively with all the issues in the } \\
\text { organization }\end{array}$ & & & & \\
\hline
\end{tabular}




\section{Self-control}

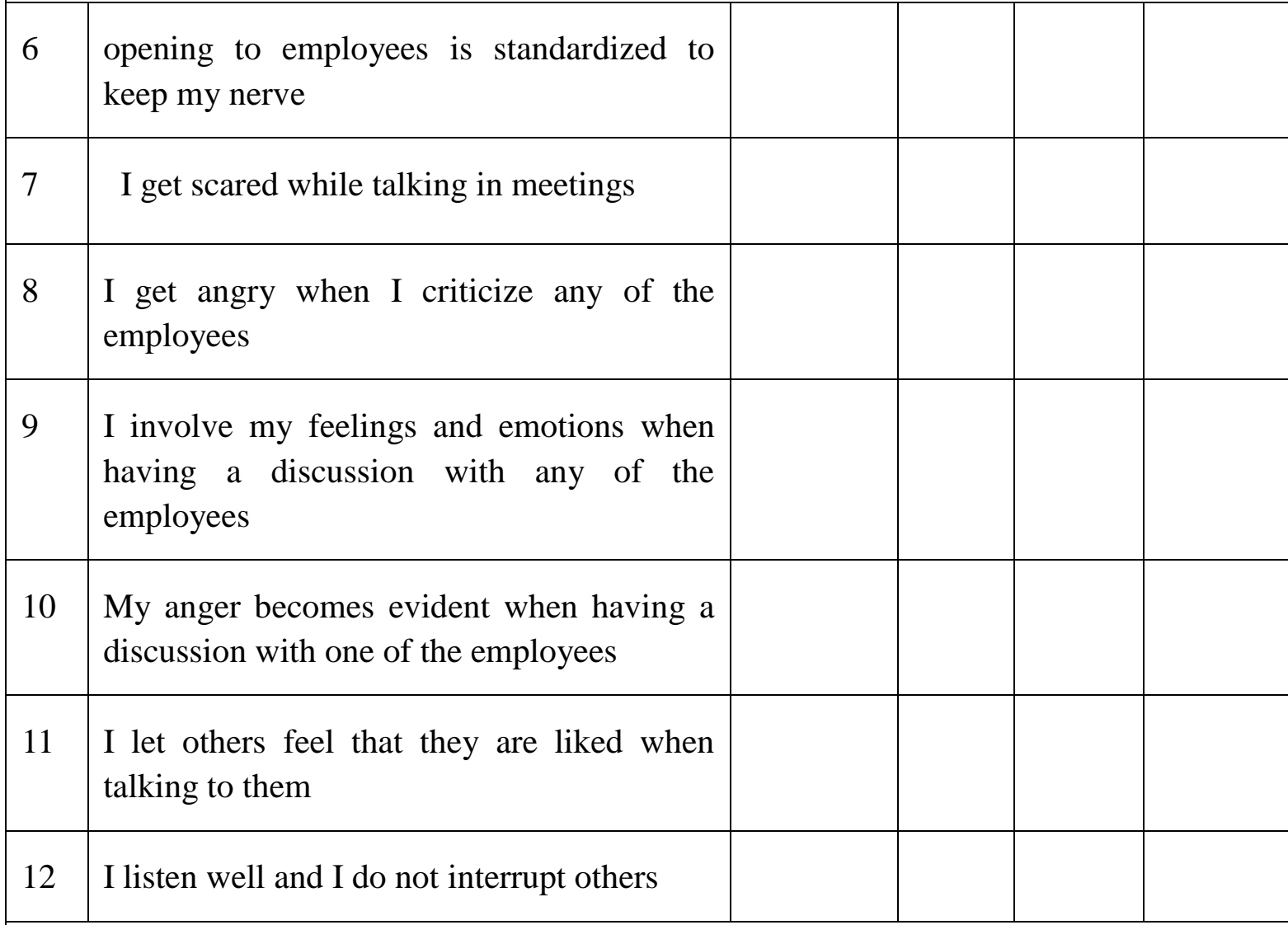

\section{Emotional balance}

\begin{tabular}{|l|l|l|l|l|l|}
\hline 13 & $\begin{array}{l}\text { I hold myself responsible after every } \\
\text { argument with any of the employees }\end{array}$ & & & & \\
\hline 14 & $\begin{array}{l}\text { after work, I sit in a quiet and contemplative } \\
\text { sessions }\end{array}$ & & & & \\
\hline 15 & I am able to quietly solve the problems & & & & \\
\hline 16 & $\begin{array}{l}\text { I am characterized by flexibility in dealing } \\
\text { with the problems }\end{array}$ & & & & \\
\hline
\end{tabular}

\section{Democratic style and decision}

17 I do not allow others to participate in the traditional decisions 


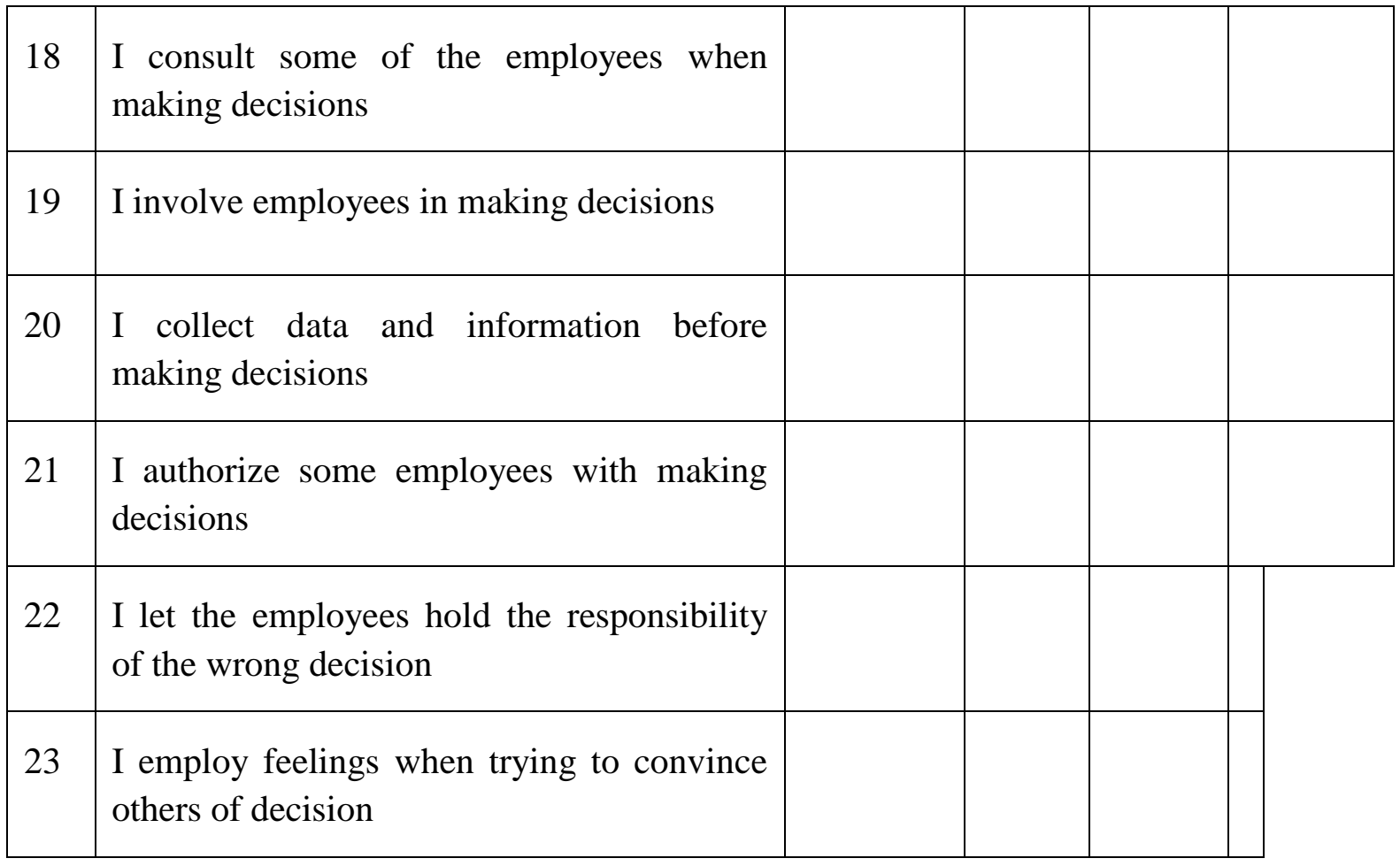

\section{Copyright Disclaimer}

Copyright for this article is retained by the author(s), with first publication rights granted to the journal.

This is an open-access article distributed under the terms and conditions of the Creative Commons Attribution license (http://creativecommons.org/licenses/by/3.0/). 